\title{
Presentation of Six Databases in Arts and Culture
}

Présentation de six bases de données portant sur les arts et la culture

Presentación de seis bases de datos sobre las artes y la cultura

\section{Claire Ducournau and Anthony Glinoer}

Translator. Michelle Arriss, Delaina Haslam and Séverine Sofio

\section{(2) OpenEdition Journals}

Electronic version

URL: http://journals.openedition.org/bssg/223

DOI: $10.4000 /$ bssg.223

ISSN: 2490-9424

\section{Publisher}

Presses universitaires de Vincennes

\section{Electronic reference}

Claire Ducournau and Anthony Glinoer, "Presentation of Six Databases in Arts and Culture", Biens Symboliques / Symbolic Goods [Online], 2 | 2018, Online since 12 April 2018, connection on 04 March 2021. URL: http://journals.openedition.org/bssg/223 ; DOI: https://doi.org/10.4000/bssg.223 


\title{
Présentation de six bases de données portant sur les arts et la culture
}

\section{Presentation of Six Databases in Arts and Culture}

\author{
Claire Ducournau | Anthony Glinoer \\ traduction | translation
}

Michelle Arriss | Delaina Haslam | Séverine Sofio

Pour refermer ce dossier, on trouvera ici des présentations brèves de bases de données conçues dans le cadre de recherches historiques ou sociologiques portant sur les arts et la culture, à partir de réponses à six questions reproduites ci-dessous. La sélection des bases de données présentées repose sur une volonté d'ouverture disciplinaire, dans la mesure où elles ne concernent plus seulement la littérature et l'imprimé, mais également les arts plastiques, la musique et le spectacle vivant. L'ambition était d'élargir les domaines abordés pour resituer l'éventuelle spécificité des études

littéraires comparativement à d'autres champs disciplinaires.

Le caractère pionnier, la rigueur et l'ampleur des bases de données constituées, qui s'inscrivent toutes au cœur de projets de recherche ayant déjà abouti à plusieurs publications, ont guidé le choix des chercheur·se·s que nous avons interrogé·e.s. Six projets, à différents
To close this dossier, below are brief presentations of databases designed for historical or sociological researches in arts and culture. These presentations are all based on six questions reproduced below. The choice of the databases presented here derives from a willingness to open the dossier to other disciplines, in so far as they deal not only with literature and print, but also with music, visual and performing arts. The aim was to enlarge the topics under discussion in order to put the potential specificity of literary studies compared with other disciplinary fields into context.

The pioneering nature, rigour, and reach of these databases, which are all integral to research projects that have already resulted in several publications, guided the choice of the researchers we questioned. Six projects - among many others - at different 
degrés d'achèvement, ont été retenus parmi de nombreux autres possibles. Björn-Olav Dozo (Université de Liège) présente la base de données sur les écrivains, les œuvres et les revues littéraires francophones belges du Collectif interuniversitaire d'étude du littéraire (CIEL) ; Éric-Olivier Lochard (Université de Montpellier 3) et Antony McKenna (Université de Saint-Étienne) la base de données ayant servi à l'édition de la correspondance de Pierre Bayle ; Solveig Serre (Centre d'études supérieures de la Renaissance/Centre de musique baroque de Versaille, CNRS) la base de données Chronopéra rassemblant les représentations données par l'Opéra de Paris depuis le XVII ${ }^{\mathrm{e}}$ siècle ; Camille Bloomfield (Université Paris-XIII), Viviana Birolli (Université Paris-I), Mette Tjell (University of Gothenburg) et Audrey Ziane (Université Aix-Marseille) la base Manart consacrée aux manifestes artistiques et littéraires au $x x^{e}$ siècle ; Josée Vincent (Université de Sherbrooke) les bases de données en histoire du livre et de l'édition montées par le Groupe de recherches et d'études sur le livre au Québec (GRELLQ) ; enfin, Béatrice Joyeux-Prunel (Ecole normale supérieure de Paris) nous fait connaître les dessous du projet ARTL@S, en particulier sa base de catalogues d'expositions organisées partout dans le monde aux $\mathrm{XIX}^{\mathrm{e}}$ et $\mathrm{XX}^{\mathrm{e}}$ siècles, projet qui a pris une envergure remarquable en termes d'interdisciplinarité, d'internationalisation, de travail en équipe et d'objectifs de formation.

Les questions posées étaient les suivantes:

1) Comment est né le projet de base de données ?

2) Comment le corpus a-t-il été délimité ?

3) La constitution de la base de données s'appuie-t-elle sur un ancrage théorique et/ou disciplinaire précis ?

4) Quels logiciels avez-vous utilisés pour bâtir l'infrastructure de la base de données, et, le cas échéant, pour son exploitation statistique? stages of progress were selected: Björn-Olav Dozo (Université de Liège) presents the Collectif interuniversitaire dDétude du littéraire (CIEL) and its database of Belgian Francophone writers, works, and journals; Éric-Olivier Lochard (Université de Montpellier 3) and Antony McKenna (Université de Saint-Étienne) present the database created to publish the correspondence of Pierre Bayle; Solveig Serre (Centre d'études supérieures de la Renaissance/ Centre de musique baroque de Versaille, CNRS) presents the Chronopéra database on performances at the Opéra de Paris from the seventeenth century; Camille Bloomfield (Université ParisXIII), Viviana Birolli (Université Paris-I), Mette Tjell (University of Gothenburg), and Audrey Ziane (Université Aix-Marseille) present the Manart database dedicated to artistic and literary twentiethcentury manifestos; Josée Vincent (Université de Sherbrooke) presents the databases on the book and publishing history, launched by the Groupe de recherches et d'études sur le livre au Québec (GRÉLQ); finally, Béatrice Joyeux-Prunel (École Normale supérieure de Paris) introduces us to the details of the ARTL@S project, particularly its database of exhibitions organized throughout the world in the nineteenth and twentieth centuries - a project that has expanded remarkably in terms of interdisciplinarity, internationalization, teamwork, and learning objectives.

The questions asked were as follows:

1) How did the database project begin?

2) How was the corpus defined?

3) Is the design of the database supported by a specific theory and/ or discipline?

4) Which software programs were used to build the database infrastructure and, as the case may be, to treat the data statistically? 
5) Pouvez-vous donner en exemple un ou deux résultats scientifiques (attendu ou surprenant) obtenus à l'aide de la base de données?

6) Qu'envisagez-vous pour la pérennité et l'accessibilité de la base de données ?
5) Could you offer one or two examples of scientific (whether consensual or surprising) results obtained with the help of the database?

6) What plans do you have with regard to the perpetuity and accessibility of this database?

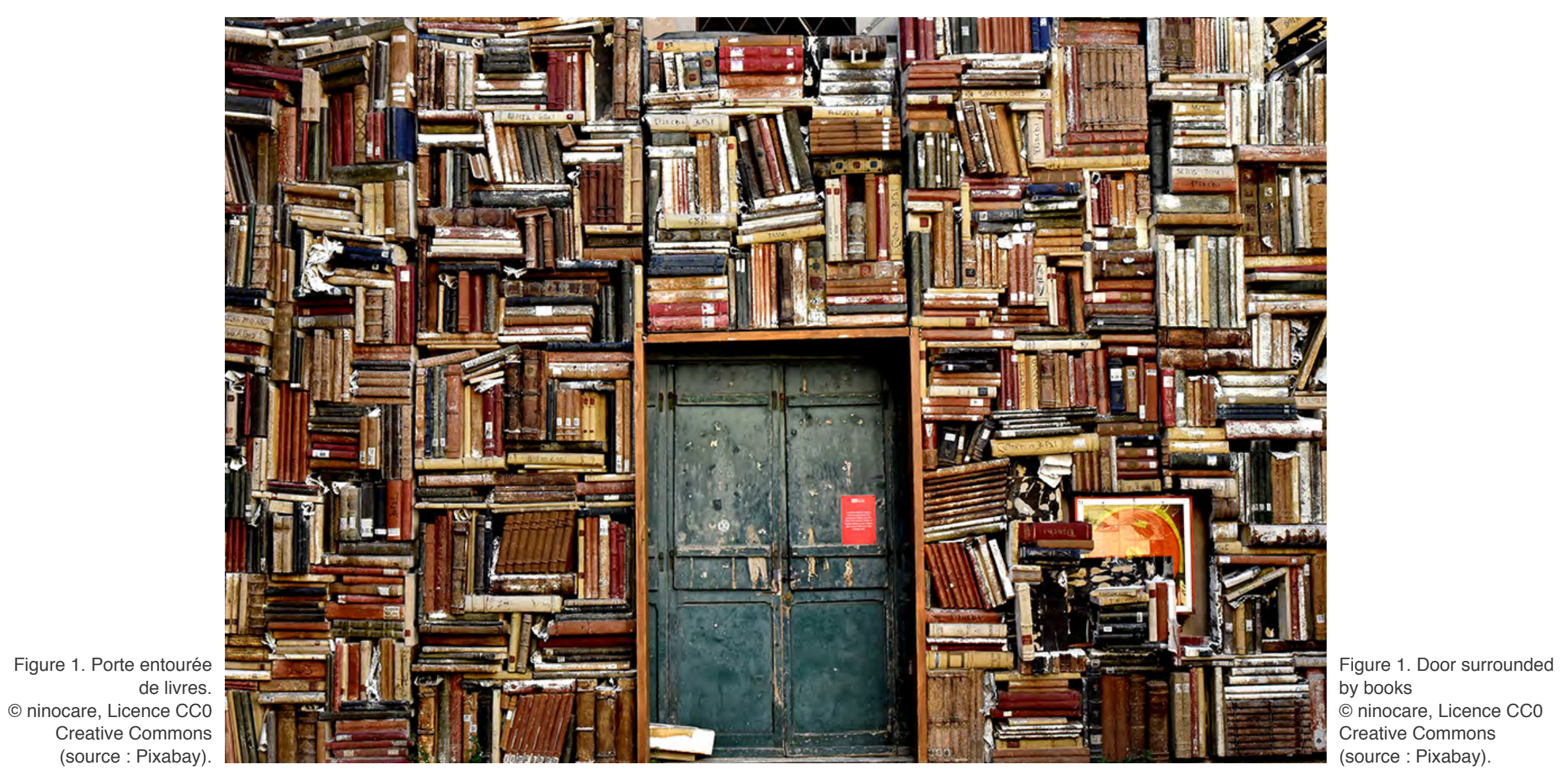


D'un projet à l'autre, la méthodologie, le corpus, la problématique de recherche changent, mais les motivations de départ sont généralement proches : insatisfaction face à une accumulation solitaire de données de grande ampleur, volonté d'utiliser au mieux des outils informatiques de plus en plus accessibles et puissants, et attrait pour un travail collectif réunissant développeur-euse-s informatiques, directeur-rice-s de projets et jeunes chercheur-se·s aux spécialités variées. Les rencontres fréquentes de l'équipe, parfois décisives, l'écriture à plusieurs des demandes de subvention, des rapports de recherche, des appels à communication, des articles, etc., ont souvent un rôle séminal pour la conception des bases de données.

Dans la plupart des cas, a été choisi pour constituer le corpus de départ un objet relativement homogène susceptible d'être rigoureusement délimité, par son existence objective (à l'instar de l'exposition, de la représentation à l'opéra, ou du livre publié), par son cadre historique et géographique (national ou international) ou encore par sa définition (le manifeste). Mais ce choix de départ ne permet de constituer le corpus - même si ses frontières demeureront objet de questionnements - qu'à l'issue d'un travail préalable de saisie et de confrontation d'archives, de sources primaires et secondaires, parfois éparses, disparates et difficilement accessibles (comme les listes de publications canadiennes avant 1960), d'où

l'intérêt de leur centralisation.

Novatrices par rapport aux modèles anthologiques ou monographiques longtemps en vogue dans les disciplines d'origine des concepteurs de ces bases (études littéraires, histoire de l'art, musicologie, etc.), ces démarches ne les ignorent cependant pas, et permettent d'y faire retour de manière critique ; elles sont également l'occasion d'envisager les œuvres awrtistiques qui en étaient l'objet, comme dans les cas de Manart, de Chronopéra ou d'ARTL@S. Au niveau du cadrage théorique, ces initiatives reposent ainsi le plus
Each project has its own methodology, corpus, and research questions. However, the initial motivation is generally similar: dissatisfaction when faced with both isolation and an accumulation of vast quantities of data; a desire for better use of digital tools that are increasingly accessible and powerful; and the appeal of collective work bringing together data processing developers, project directors, and young researchers from various fields. Frequent, and sometimes decisive, team meetings, collective preparation of grant applications, research reports, and calls for papers, articles, etc. often play a seminal role in the design of the databases.

In most cases, the baseline corpus was a relatively homogenous object that was susceptible to being rigorously delineated by its objective existence as events or objects (such as an exhibition, opera performances, or published books), by its historical or geographical framework (national or international), or by its definition (the manifesto) - and even then, the corpus' limits can still be open to debate. However, this is only a first stage, since the corpus itself is actually the result of the preliminary work of collecting and delving into archives, into primary and secondary sources that are sometimes scarce, disparate, or difficult to access (such as lists of Canadian publications before 1960) - hence the interest in centralizing them.

Such approaches are innovative compared with the anthology or monography models that have long been in vogue in the original disciplines of these databases (literary studies, history of art, musicology, etc.), but they still rely on and invite a critical reconsideration of such models; they also offer the opportunity to take into account the artistic works on which they are based, as in the case of Manart, Chronopéra, and ARTL@S. As for the theoretical frameworks, these initiatives are most often grounded 
souvent sur une interdisciplinarité assumée, établissant des liens avec l'histoire sociale et la sociologie, voire la géographie (pour ARTL@S, qui se singularise aussi par son caractère transnational et dé-

colonial).

Les logiciels utilisés varient mais les équipes ont de plus en plus opté avec le temps pour des logiciels libres, comme MySQL - le cas d'Arcane, logiciel développé parallèlement au travail sur la correspondance de Bayle, a nécessité ici davantage de développements, utiles pour en mesurer les apports propres.

Les résultats auxquels les bases contribuent à aboutir imposent de revisiter des chronologies ou des géographies admises (témoignant par exemple d'un changement de nature du manifeste, de plus en plus souvent signé à titre individuel à partir des années 1980), ou de préciser l'importance et la connaissance de certains acteurs culturels, comme ceux que Björn Olav-Dozo nomme ici les « animateurs » de la vie littéraire en Belgique francophone, qui se sont vus identifiés, localisés et étudiés par le CIEL. L'enjeu de ces bases devient ainsi souvent double : patrimonial et scientifique. Mettant en lumière des zones, des ouvrages ou des individus méconnus, les bases de données permettent d'une part de tracer les contours d'histoires artistiques ou littéraires renouvelées, voire " subversives » (selon la formule de Béatrice Joyeux-Prunel) et d'en conserver les archives. Mettant d'autre part des données en série, elles rendent possible leur exploitation statistique ou graphique à partir de différents outils : représentation d'un espace social, analyse de réseaux, géolocalisation par exemple.

À l'arrivée, l'accessibilité des données accumulées constitue un réel enjeu, nécessitant du temps de travail et donc des investissements financiers. Les différents projets cherchent à rendre leurs résultats publics, là encore dans une démarche conjointement patrimoniale in an assumed interdisciplinarity, creating links with social history, sociology, and even geography (in the case of ARTL@S, which distinguishes itself through its transnational and decolonial nature).

The software used varies but the teams have increasingly opted for open-source options such as MySQL. The case of Arcane, a software developed alongside the work on the Bayle correspondence, required many useful developments in this regard.

The results achieved thanks to these databases allow to revisit accepted chronologies or geographies (giving evidence, for example, of a change in the nature of the manifesto, increasingly signed by individuals from the 1980s onwards), or to clarify the importance and knowledge of certain cultural players, such as those that Björn Olav-Dozo calls the "animators" of Francophone literary life in Belgium, who are identified, located, and studied by CIEL. Thus, the issue of these databases often pertains both to heritage and to science. Bringing to light lesser-known geographical areas, works, or individuals, these databases on the one hand help to write renewed, and sometimes "subversive" (to quote Béatrice Joyeux-Prunel), artistic or literary histories, and to preserve the archive. On the other hand, by putting the data in series, they make their statistical or graphic treatment possible via different tools: social space modelling, network analysis, or geolocalization, for example.

In the end, how to access the amassed data is a real challenge, requiring time, effort, and therefore financial investment. The various projects seek to make their results public, there again in a joint heritage and scientific approach. Only by making a simplified interface with a research engine available to the public, 
et scientifique. Par la seule mise à disposition du public d'une interface simplifiée avec moteur de recherche, les équipes invitent les chercheur.se's à s'en saisir pour concevoir ou étudier de nouveaux objets de recherche. Cette accessibilité est souvent pensée en partenariat avec des institutions susceptibles d'en assurer la pérennité (comme la TGIR - Très grande infrastructure de recherche - Huma-Num), et conjointement à la publication d'articles, de thèses et d'ouvrages (c'est le cas du GRÉLQ au Québec et du CIEL en Belgique, par exemple)

La lecture de ces présentations donnera donc, nous l'espérons, à la lectrice et au lecteur une idée des recherches sociohistoriques menées dans l'espace francophone sur les arts et la littérature au moyen de bases de données.

Claire Ducournau Université Paul-Valéry-Montpellier 3 - RIRRA21

Anthony Glinoe

Université de Sherbrooke - Chaire de recherche du Canada sur l'histoire de l'édition et la sociologie du littéraire the teams invite researchers to use it to conceive or study new objects of research. Data availability is often made possible thanks to a partnership with specialized institutions, likely to assure the database's perpetuity (as French Huma-Num, a "Very Large Facility which aims to facilitate the digital turn in humanities and social sciences"), and in conjunction with the publication of articles, theses, and other works (this the case for the GRELQ in Quebec, and the CIEL in Belgium, for example).

We hope, therefore, that reading these presentations will give readers an overview of some of the socio-historical researches being conducted into arts and literature in the Francophone space by means of databases.

\section{Claire Ducournau}

Université Paul-Valéry-Montpellier 3 - RIRRA21

Anthony Glinoer

Université de Sherbrooke - Chaire de recherche du Canada sur l'histoire de l'édition et la sociologie du littéraire 